\title{
Determining the Seasonal Ornithological Potential of the Dönemeç (Engil) Delta and Generate the Digital Maps Using Geographical Information Systems (GIS)
}

\author{
Emrah ÇELİK ${ }^{1}$, Atilla DURMUŞ ${ }^{1}$
}

\begin{abstract}
This research was performed in one of the important bird areas in Lake Van Basin, at Dönemeç (Engil) Delta, (Van - Turkey) from April 2011 to April 2012. A total of, 91 species and 1 subspecies belongs to 34 families were determined. Out of total, $34.7 \%(\mathrm{n}: 32)$ species were residents, $53.2 \%$ (n:49) were summer visitors, $4.43 \%(\mathrm{n}: 4)$ winter visitors, $6.52 \%(\mathrm{n}: 6)$ non - breeding transit migrants and 1.08\% (n:1) random species. According to International Union for Conservation of Nature (IUCN) criterias, it was observed that one species was endangered (EN), one species was near threatened (NT), one species was vulnerable (VU) and 89 species were least concern (LC). The distribution of the species population in the area at six different habitats has been identified and habitats of the endangered species, in particular, have been highlighted by creating GIS-based distribution maps.
\end{abstract}

Keywords: ArcMap, conservation, ornithofauna, Van lake basin, wetland

\section{Dönemeç (Engil) Deltası’nın Mevsimsel Ornitolojik Potansiyelinin Belirlenmesi ve Coğrafi Bilgi Sistemleri (CBS) Kullanılarak Sayısal Haritaların Oluşturulması}

ÖZET: Bu araştırma Van Gölü Havzası'ndaki önemli kuş alanlarından biri olan Dönemeç (Engil) Deltası'nda gerçekleştirildi. Nisan 2011 ve Nisan 2012 tarihlerini kapsayan bir yıllık arazi çalışmaları sonucunda 34 familyaya ait 91 tür ve 1 alttür tespit edildi. Bu türlerin 34.7\% (32) Yerli, 53.2\% (49) Göçmen, 4.34\% (4) Kış ziyaretçisi, 6.52\% (6) Transit Göçer, 1.08\% (1) Rastlantısal tür olduğu belirlendi. Alandaki türler Uluslararası IUCN kriterlerine göre değerlendirildiğinde; 1 türün EN (Endangered), 1 türün VU (Vulnerable-Hassas), 1 türün NT (Near Threatened) ve 89 türün LC (Least Concern) statüsünde olduğu belirlendi. Alandaki türlerin, altı farklı habitatta populasyon dağılımı belirlenmiş, özellikle nesli tehlike altındaki türlerin yaşam alanları GIS tabanlı dağılım haritaları oluşturularak öne çıkarılmıştır.

Anahtar kelimeler: ArcMap, koruma, ornitofauna, sulakalan, Van gölü havzası

Yüzüncü Y1l Üniversitesi, Fen Fakültesi, Biyoloji, Van, Türkiye

Sorumlu yazar/Corresponding Author: Emrah ÇELIK,celikemrah822@gmail.com 


\section{INTRODUCTION}

Currently, Geographic Information Systems (GIS) is commonly used to monitor and conserve the avian species and their habitats in order to reduce the threats and to enhance their population such as in coastal regions (Mironga, 2004), in Matsula wetland west of Estonia (Magi et al. 2004), wetlands of Pakistan (WWF, 2007), and coastal and water birds in coastal regions of California (Stralberg, 2010). Habitat preferences by feeding areas of water birds which feed by diving and from surface in their study conducted in Delta Marsh in Canada, in this study in which GIS analysis technique was used, it was conducted that habitats where species are fed seasonally change in relation with vegetation density and water depth. It was emphasized that this condition should be taken into account in the conversation studies to be conducted in the area (Murkin et al., 1997; Nergiz and Durmuş, 2017). In Turkey, GIS (Geographic Information System) applications have started to be used in many different areas from urban planning to species and area conservation studies particularly in recent years. Besides, it was be used in determination of pollution parameters in wetlands wetlands (Doygun et al., 2003; Gündoğdu et al., 2007; Artar, 2008; Demir, 2008). However, GIS applications were used in ornithological studies (Onmuş, 2006; Açıkgöz, 2010). Dönemeç Delta has a rich avifauna potential due to its different habitat types. Including the geographical information systems, this study includes the life spaces of the existing bird species in particular to the endangered ones in accordance with the international criteria and allows for preserving and monitoring activities toward such species and habitats.

\section{MATERIAL AND METHOD}

The material of this study involves Dönemeç (Engil) Delta $\left(38^{\circ} 20^{\prime} \mathrm{N} / 43^{\circ} 09^{\prime} \mathrm{E}\right)$, which is one of the Important Bird Areas in Van Lake Basin in Turkey, and the birds that use the delta as for living purposes. We analyzed habitat preference of the bird species that stay and produce in the nutrition and breeding sites, the number of species, their population size, ecological and biological needs, threatening factors (Hunting pressure, overgrazing, reed cutting, egg collection, drainage) toward species and life spaces and necessary precautions to take. For this purpose, we have carried out counting and observation between April 2011 - April 2012. We have conducted observations for identifying the density of the population as a field work for one year as 15 days period on each month. The observations, concentrated on the reproduction periods have been conducted between $6^{00}-11^{00} ; 15^{00}-19^{00}$ hours when the individuals are active. The study area is divided into 76 UTM squares of $1 \times 1$ $\mathrm{km}^{2}$ (Figure 1). Each UTM has 3 observation points to represent the habitats present on the surface and to be at least 300 meters from each other. Observations were made at each observation point for a fixed duration of 15 minutes. Bird species, population numbers and UTM coordinates detected in the surroundings of the point and the surroundings were recorded on the land observation cards. The point records obtained as a result of the process are then assigned to UTM squares. Thus, for each UTM square, there are 3 point scrolling and UTM square center point data that 3 points records are assigned. This process allows the possibility of analysis on a grid basis besides the point scale (Onmus, 2008). Line transects and Point counts were used to observe the number of the individual and population density (Bibby and Burgess, 1992). We utilized Kiziroğlu (2009; 2010) in identifying the species. Topographic maps were generated with $1 / 25.000$ scale by taking the coordinates of the Dönemeç Delta and different habitats within it and such maps are transferred to the digital environment and they laid the groundwork for all activities to be done in GIS environment. We have generated the maps for preserving the space and species with GIS analysis methods and had outputs to create the basis for the management plan. We have used ArcMap 10.2 software based on GIS for analyzing and the creation of the data from the digital data.

\section{RESULTS AND DISCUSSION}

It was found that $34.7 \% \quad(\mathrm{n}: 32)$ species were residents, $53.2 \%$ (n:49) were summer visitors, $4.43 \%$ (n:4) winter visitors, $6.52 \%$ (n:6) non- breeding transit migrant and $1.08 \%$ (n:1) random species. Also, it was determined that 30 species absolutely breed, 15 species probably breed and 47 species do not breed in this area.

As a result of assessment of species living in the area by IUCN criteria's; it was seen that 1 species was 
EN (Oxyura leucocephala), 1 species was VU (Aythya ferina) 1 species was NT (Limosa limosa,) and 89 species were LC. 92 species were identified within 6 different habitat types determined in Dönemeç Delta. In this study, Spur-winged Lapwing (Hoplopterus spinosus) was recorded at Dönemeç Delta for the first time in Lake Van Basin. While some of species birds uses these habitats for breeding, and others uses for feeding and safekeeping purposes. Considering the seasonal distribution of the species, they use different habitats on every season. A large area of reeds and swarms are formed as a result of the spread of water at the place where Dönemeç (Engil) creek pours into the Van Lake. We observed that the level of water increased day by day due to the extreme rainfall, especially in spring. In that case, this place has turned into a suitable habitat for ducks, who feed on by diving and grebes species. The close-timbered reeds have turned into fields where bird species can maintain their vital activities such as reproduction and hiding. It is observed that the bird species in the area prefer common habitats in the summer seasons as they do in the spring. The bird species use these areas extensively for there are many foods and a minimum level of negative environment conditions such as pollution and hunting (Figure 2). Dönemeç Delta is an important assembly area for the migrating birds in particular to in autumn season. The bird species have spread over the reeds and mud flats that are formed in the areas where freshwater is mixed with the lake according to the observations conducted in autumn. It has been identified that the bird species zero in some specific areas to feed on for food resources decrease due to the reduction of the water level in this season (Figure 3). The winter is cold and long in the region. The winter migratory and local species zero in such fields for a large part of the Delta is covered with snow and only the regions of Engil creek mixing with the lake do not freeze (Figure 4). The habitat type of meadow and pasture is dominant in the region for drainage channel in the middle of the Delta pulls the water that is spread over the surface. This area experiences grazing pressure, which is the common livestock grazing place for the surrounding villages. This influences the distribution of the bird species that use the area for feeding (Figure 5).
As it is indicated in Fig. 5, the lettering system has been used for the distribution of the species in the field and five different color scales have been created in line with the density. The UTM squares are marked with "A" are the areas where bird species spread out less often due to their proximity to the settlement and high anthropogenic pressures. The bird species spread out to the mudflats in the south part of the region where the creek is mixed with the lake and planted agricultural lands and streamside during the spring in the areas marked with "B". The UTM squares marked with "C" represent woodlands, mud flats, partly wet meadows and reeds and localities where the birds can easily find food and hide. The areas marked with "D" are the suitable habitats for feeding and preservation, where close-timbered reeds are available and have lesser grazing pressure. The bird species perform their vital activities such as feeding and hiding in such areas. The areas marked with "E" in the map represents the dune flats in the form of an island, where it is hard for people to reach and involves the sections where Engil Creek is mixed with the lake and there are swarms and close timbered reeds that are fully isolated. These localities are an extremely favorable environment for the birds. Living in Van Lake and being an endemic fish species, the pearl mullet (Alburnus tarichi Güldenstädt, 1814) passes the Engil Stream in spring, facilitating the feeding of the bird species and eliminate the problem of finding food. The birds use this area both for feeding and reproduction (Figure 6)

The limits of the reproduction regions of the bird species have been determined in the observations conducted during spring (March - April). We have created three different color scales to identify the even number of the bird species, reproducing in the basin. We have used some symbols to show the color scale created. The UTM squares marked with "-" on the map are the localities that are preferred less often as a nesting site. The main reason for this was the environmental factors experienced in these regions (overgrazing, hunting pressure, lack of food, etc.), and proximity to the settlements, and lack of suitable habitats. At the same time, the area gets drier and turns into the unfavorable environment for the water, which once spread over the area, poured down to the lake through drainage channel. The UTM squares marked with " $\mathbf{x}$ " on the map have 
lesser negative environmental factors, defined above. Therefore these areas were suitable for reproduction. The UTM squares marked with "+" on the map are the regions which were covered with close-timbered reeds, and swarms that were hard to enter and sandy place. In particular, the birds frequently preferred these habitats as a nesting area during the breeding period. The main reason is the preserved nesting areas, provision of necessary food for caring the offspring and lack of external environment pressure. By this way, the chance of survival of the offspring improves and their risk and rate of death decreases. By this way, it positively contributes to the reproduction success of the water birds in the area. Furthermore, it has been observed that 9 pairs of the endangered Oxyura leucocephala duck shown in the region as "+" on the map are reproduced and their offspring fully matured and flown. It indicates that reproduction success of the species is high and it is important for the continuation of generation of the species.

In this study, we have identified 91 species and 1 subspecies of 34 families as a result of one-year field work that is between April 2011 and April 2012. We have identified $34.7 \%$ (n: 32 ) species were residents, $53.2 \%(\mathrm{n}: 49)$ were summer visitors, $4.43 \%$ (n:4) winter visitor, $6.52 \%$ (n:6) non- breeding transit migrant and $1.08 \%(\mathrm{n}: 1)$ random species. It has been defined that 30 species out of the available species have certainly reproduced, 15 of them have probably reproduced and 47 of them have not reproduced yet. Adizel $(1993 ; 1998)$ has identified 148 species of birds in Van Lake Basin. The species identified herein were in parallel with the 148 species that were identified before. However, Hoplopterus spinosus which has not been identified and seen in the basin before is identified by us in the Dönemeç Delta for the first time. Oxyura leucocephala, which was recorded in the field by the study conducted in 1998, and was involved in the Endangered category, reproduced 9 pairs in 2012 and all of these offspring are matured and flew. It indicates that reproduction success of the species is high and it is important for the continuation of generation of the species.

Habitat preference of the water birds, feed on diving and on a surface according to their feeding area in their study, conducted in the Delta Swarm in Canada by using GIS (Murkin et al., 1997). At same time it was analyzed the habitat selection and distribution of the Anas platyrhynchos in their study in wetlands in Saginaw Bay in the USA.

They created the distribution map of the species in the area by using GIS and obtained outputs about the field management. However, we have identified the habitat preference and density of the birds in the delta and assessed them on GIS that is different from these two studies (Strauss, 2008). Seasonal change of the water level in the wetlands is significant for the species that stay in such areas and the decrease and increase of water plants depending on the change of water level has a direct influence on the field preference of the water birds (Holm and Clausen, 2006). This study is similar with our work.

Our study proved that wetlands dry up due to the decrease of Engil Stream during summer, which is the only source to provide water to the delta and species get close to the lake to feed on and move up closer to some specific area. These conditions were disadvantage for species in summer.

\section{CONCLUSION}

Our study suggests, it is ornithologically important that the basin has a wide range of area and accommodates different habitat types. The reason why each species has an extensive potential is that there are different habitat types and such habitats support vital activities according to the research conducted during four seasons. The migratory and winter migratory birds that visit the area have extensive activity in the place where delta pours down in the Van Lake. The fact that the Dönemeç Delta is located on the Van-Gevaş highway and that there is no transportation problem as well make the ornithological richness, the area has a great ecotourism and bio-tourism potential. For this reason, public institutions, civil society organizations, local authorities and the media have to work in cooperation and ensure that available potential should add a significant contribution to the region.

\section{Acknowledgement}

This study was summarized from Master thesis project (FBE-YL004) supported by Scientific Research Project Management unit of Yuzuncu Yil University. 


\section{REFERENCES}

Doygun H, Berberoğlu S, Alphan H, 2003. Determination of land usage changes of Hatay, Burnaz coastal dunes with remote sensing method. Ecology, 12: 4-9.

Holm ET, Clausen, P, 2006. Effects of water level management on autumn staging waterbird and macrophyte diversity in three Danish coastal lagoons. Biodiversity and Conservation, 15: 4399-4423.

Mägi E, Kastepõld T, Lotman A, 2004. Ornithological monitoring and wetland management in Matsalu. Bird Census News, 13: 139-144.

Mironga JM, 2004. Geographic information systems (GIS) and remote sensing in the management of shallow tropical lakes, South Carolina. Applied Ecology and Environmental Research, 2(1): 83-103.

Murkin HR, Murkin EJ, Ball JP, 1997. Avian habitat selection and Prairie wetland dynamics: A 10 year experiment. Ecological Applications, 7(4): 1144-1159.

Nergiz H, Durmuş A, 2017. Effects of habitat change on breeding waterbirds in Arin (Sodali) Lake, Turkey. Applied Ecology And Environmental Research, 15(3): 1111-1118.

Stralberg D, Cameron DR, Reynolds MD, Hickey CM, Klausmeyer K, Busby SM, Stenzel LE, Shuford WD, Page GW, 2010. Identifying habitat conservation priorities and gaps for migratory shorebirds and waterfowl in California. Biodiversity Conserv, DOI 10.1007/s10531-010-9943-5.

Gündoğdu V, Akgün G, Elele M, Piyancı O, 2007. Examination for the change in the quality of GIS-based observations in the years 2001-2006, in Gediz River sub basin. Congress for National Geographic Information Systems, 30 October-2 November, KTÜ, Trabzon.

Onmuş O, 2006. Use of geographic information systems in order for monitoring and managing of important bird areas, Case study for important bird area of Gediz Delta. 4. Geographic Information Systems Days, 13-16 September, İstanbul.
Açıkgöz G, 2010. Using remote sensing and geographic information systems to detect changes in the ovaries of coastal wetland system. Çukurova University, Institute of Science and Technology, (Unpublished) Master's thesis $79 \mathrm{p}$.

Adızel Ö, 1998. Researches on Van Lake Basin Ornithofauna. Y Y Ü, Institute of Science and Technology, (Unpublished) Ph.D. thesis Van.

Artar M, 2008. Development of a method for monitoring protected areas, in the example of Karatepe-Aslantaş National Park. Çukurova University, Institute of Science and Technology, (Unpublished) Ph.D. thesis 276 p.

Demir A, 2008. Identification of the geographic information system aided distribution by determining salinity and some pollution levels in Akyatan Lagoon. Çukurova University, Institute of Science and Technology, Master's thesis $206 \mathrm{p}$.

Onmuş O, 2008. Observation of nesting areas of breeder species in Gediz Delta and the management of these colonies. Ege University, Institute of Science, Ph.D. thesis $207 \mathrm{p}$.

Strauss B, 2008. Nesting mallard (Anas platyrhynchos) habitat selection and management using GIS. Duke University, The Nicholas School of the Environment and Earth Sciences, Master's thesis $34 \mathrm{p}$.

WWF Pakistan, 2007. Pakistan wetland GIS implementation strategy, Draft Discussion Paper, Pakistan Wetland Programme, Islamabad, $80 \mathrm{p}$

Bibby CJ, Burgess ND, 1992. Bird Census Techniques. Academic Pres Limited, NW1 7DX, London. 257 p.

Kiziroğlu İ, 2009. Pocket Book for Turkish Birds. Ankamat Printing, Ankara. 564 p. 